J. Perinat. Med. 1 (1973) 13

\section{The inhibitory action of Diazoxide on uterine activity in the subhuman primate: Placental transfer and effect on the fetus}

\author{
Hisayo O. Morishima, Harry Cohen, Walter U. Brown, Salha Daniel, \\ Wendell H. Neimann, L. Stanley James
}

Division of Perinatal Medicine of the Department of Anesthesiology, Obstetrics and Gynecology and Pediatrics, College of Physicians and Surgeons, Columbia University and Babies Hospital, New York, N. Y.

Received September 29, 1972. Accepted October 10, 1972.
A drug to suppress uterine activity with minimal or no side effects would be valuable for the prevention of premature or precipitous labor, or for the control of tetanic uterine contractions. Recently it has been reported that diazoxide*, a benzothiadiazine derivative, a smooth muscle relaxant [15] inhibits myometrial activity of the human uterus $[3,9]$ with no apparent adverse reactions on the fetus $[5,8]$. However, the dose necessary to suppres uterine activity also causes maternal hypotension [5] and the drug has other pharmacologic actions including the induction of hyperglycemia.

Because of the lack of direct information on the effect of the drug on the fetus, pilot experiments were conducted in our laboratory on the pregnant guinea pig and her fetus [11]. Blood glucose rose to a similar degree in both mother and fetus, and when delivered, the fetuses were acidotic and severely depressed, probably as a result of maternal hypotension. On the basis of these observations, it was felt that possible adverse effects of the drug on the fetus should be examined more carefully. This paper describes experiments on pregnant subhuman primates in which the inhibiting action of diazoxide on uterine activity, placental transfer of the drug and its effect on the cardiovascular and biochemical state of both mother and fetus were studied.

\footnotetext{
* Hyperstat ${ }^{\circledR}$ (Schering Corporation, USA).
}

\section{Curriculum vitae}

Hisayo O. Morishima, M. D., Pb. D., is an Assistant Professor of Anesthesiology at Columbia University, College of Plbysicians and Surgeons, New York City. A native of Japan, Dr. Morisbima graduated from Tobo University School of Medicine in Tolyo and served as a Resident in Anestbesiology bozls at Tokjo University and at District of Columbia General Hospital and Washington Hospital Cen-

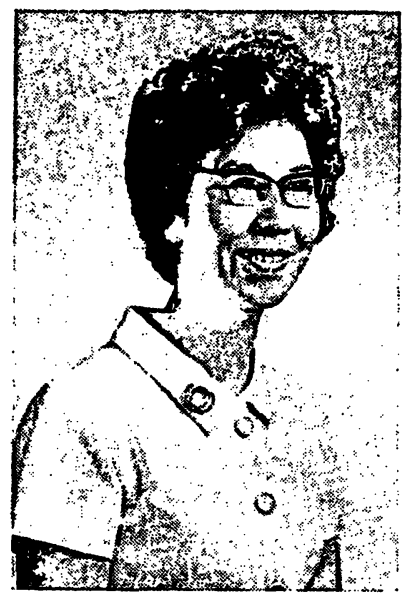
ter in Wasbington, D.C. Sbe earned ber Pb. D., in Medicine from Tokyo University, Japan. Fetal and neonatal pbysiology' and pharmacology and obstetric anestbesia are ber special researcls interests.

\section{Material and methods}

Experiments were conducted on a total of 31 pregnant primates. These consisted of 9 rhesus monkeys (maccaca mulatta) and 7 java monkeys (maccaca fasicularis), at gestational ages ranging from 132 to 155 days (term 168 days), and 15 baboons (papio hybrid) at gestational ages ranging from 150 to 171 days (term 185 days). Acid-base data from $\mathbf{4 2}$ additional pregnant primates studied earlier are included in order to evaluate changes in acid-base state of the fetus following the infusion of diazoxide.

The model used has been described previously in detail [7]. Briefly, catheters were placed in the fetal carotid artery or femoral artery and amniotic fluid at hysterotomy, and in the maternal femoral artery and vein. In addition, thermistor probes were placed in the fetal csophagus and maternal rectum. Post-operatively, light sedation was 
maintained with nitrous oxide and oxygen [12]. Maternal and fetal arterial pressure, heart rate, and amniotic fluid pressure were monitored and recorded continuously. Following the operative procedure, recovery of both mother and fetus was monitored for a period of 2 hours. During this time, uterine contractions commenced spontaneously in 20 animals; in 15 of these, a well-established labor developed while in 5 , the contractions remained mild as in early labor. In the remaining 11 , uterine contractions were induced with oxytocin (8 animals) or prostaglandin $\mathrm{F}_{2} \alpha$ (3 animals). Oxytocin was administered $\mathrm{I}$. V. at a rate of 5-20 milli-units per minute depending on the dose necessary to increase uterine activity to a level comparable to that seen during spontaneous labor. Prostaglandin $F_{2} \alpha$ was administered I. V. at a rate of 0.3 to $0.6 \mathrm{mg} / \mathrm{kg} / \mathrm{min}$; infusion rate was kept constant throughout the experiment. The uterine activity following induced labor was $187 \pm 20.2$ (S. E.) Montevideo units [1], and of similar intensity to that seen in spontaneous labor, $216 \pm 19.9$ (S. E.) Montevideo units. In the 5 animals where uterine activity was comparable to early labor, the intensity of activity was calculated to be between 90 and 120 Montevideo units.

Diazoxide was infused intravenously into 21 animals while isotonic saline was infused into the remaining 10 , which formed the control group. The infusion was begun at the end of the recovery period when either spontaneous or induced labor was well-established. The diazoxide solutions were made from Hyperstat ${ }^{\circledR}$ (Schering Corporation, USA) (supplied in $20 \mathrm{ml}$ ampules in a concentration of $15 \mathrm{mg} / \mathrm{ml}$ ) which was diluted to $2 \mathrm{mg} / \mathrm{ml}$ in isotonic saline.

The drug was administered in three ways: (a) in a graded dose to determine dose response, group I, 10 animals, tab. 1; (b) as a bolus in an attempt to suppress uterine activity acutely, group II, 6 animals, tab. 2 (this is the technique which has been used clinically in humans); (c) in a low dosage as a slow, prolonged infusion in the 5 animals with only mild uterine activity, group III, tab. 3. In group I, diazoxide was infused for approximately 60 minutes, the dose ranging from 6.2 to $62.7 \mathrm{mg} / \mathrm{kg}$ with an infusion rate of 0.11 to $1.10 \mathrm{mg} / \mathrm{kg} / \mathrm{min}$; the lowest dose was chosen since it was similar to that given in clinical investigation of pregnant humans $[5,8]$. For group II, $6 \mathrm{mg} / \mathrm{kg}$ was given as a bolus. In group III, a $1 \%$ solution of diazoxide was administered for a period of 4-7 hours, total dose ranging from 180 to $300 \mathrm{mg}$ with an infusion rate of $0.043-0.057 \mathrm{mg} / \mathrm{kg} / \mathrm{min}$. In the 10 animals which formed group IV (control) isotonic saline was infused at a comparable rate to the infusion given to the diazoxide group.

Blood samples were withdrawn from arterial catheters periodically throughout the experiment for determination of $\mathrm{pH}, \mathrm{PCO}_{2}$ and $\mathrm{PO}_{2}$ using Radiometer microelectrodes. The base deficit was calculated by means of the Radiometer blood gas calculator. Blood was obtained from the maternal and fetal arteries for glucose determination in 14 experiments and for measurement of diazoxide concentration in 9 experiments. Glucose content was measured by the glucose-oxidase method; diazoxide concentration was determined by a modification of the method described by Calesnick [2]. Warm maternal blood, drawn prior to the study, was periodically replaced into the fetal circulation following fetal blood sampling.

\section{Results}

\subsection{Uterine Activity}

There was a reduction in the intensity of uterine activity within a few minutes, of commencing

DIAZOXIDE INTRAVENOUS INFUSION (Img/ $\mathrm{kg} / \mathrm{min})$

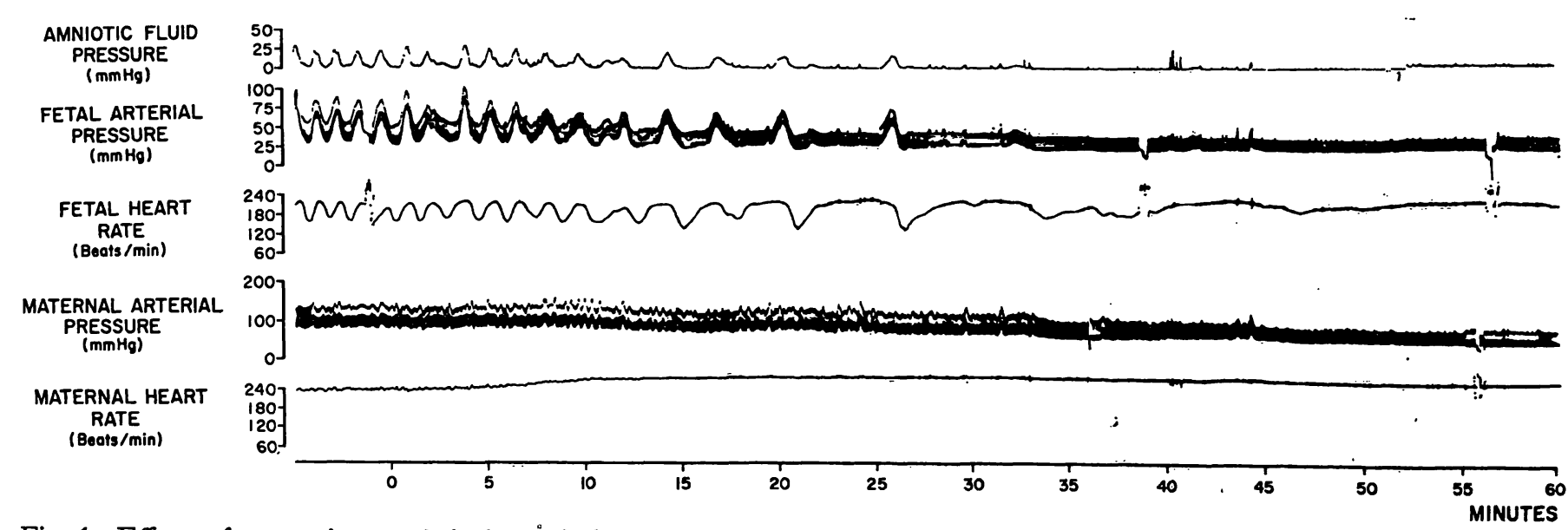

Fig. 1. Effect of a continuous infusion of diazoxide on uterine activity, blood pressure and heart rate of mother and fetus. Note the disappearance of late deceleration of the fetal heart rate with cessation of uterine contractions. (Animal J19, tab. 1). 
the diazoxide infusion (fig. 1) and within 30 minutes, activity was suppressed $50 \%$ in all but one animal, irrespective of whether labor was spontaneous or induced (tab. 1). The time to respond was somewhat variable. Following the termination of diazoxide, sustained inhibition continued for 30 minutes or longer and in those animals receiving the largest dose, the inhibiting action lasted for over 2 hours. In the second group of animals receiving the bolus injection of diazoxide,

Tab. 1. Effect of I. V. infusion of diazoxide on uterine activity (Group I).

\begin{tabular}{lccccccc}
\hline Animal & $\begin{array}{c}\text { Gestation } \\
\text { (days) }\end{array}$ & $\begin{array}{c}\text { Type } \\
\text { of Labor }\end{array}$ & $\begin{array}{c}\text { Diazoxide } \\
\text { Totaldose } \\
\text { (mg/kg) }\end{array}$ & $\begin{array}{c}\text { Infusion rate } \\
(\mathrm{mg} / \mathrm{kg} / \mathrm{min} \text { ) }\end{array}$ & $\begin{array}{c}\text { Time required to suppress } \\
\text { uterine activity (min.) } \\
\text { 50\% }\end{array}$ & $\begin{array}{c}\text { Recovery to pre-infusion } \\
\text { level (min.)** }\end{array}$ \\
\hline R25 & 157 & Spontaneous & 6.2 & 0.11 & 30 & 45 & 30 \\
R20 & 140 & Induced & 6.3 & 0.13 & 20 & 30 & 36 \\
B38 & 158 & Spontaneous & 6.3 & 0.13 & 10 & never reached & 31 \\
J8 & 151 & Induced & 12.3 & 0.18 & 23 & 60 & 40 \\
R14 & 148 & Induced & 12.5 & 0.17 & 60 & never reached & 30 \\
J16 & 148 & Spontaneous & 12.9 & 0.23 & 17 & 30 & 66 \\
J10 & 155 & Spontaneous & 50.9 & 0.77 & $11 / 2$ & 40 & $1 / 2$ recovery at 300 \\
R24 & 145 & Spontaneous & 60.0 & 1.00 & immediatc & immediate & $1 / 2$ recovery at 260 \\
J17 & 158 & Spontaneous & 61.9 & 0.74 & 30 & 42 & 158 \\
J19 & 148 & Induced & 62.7 & 1.10 & 15 & 30 & 130 \\
\hline
\end{tabular}

* Represents changes in Montevideo unit from pre-infusion values.

** Time following completion of diazoxide infusion.

Tab. 2. Effect of a bolus injection of diazoxide $(6 \mathrm{mg} / \mathrm{kg})$ on uterine activity (Group II).

\begin{tabular}{lcllcl}
\hline Animal & $\begin{array}{c}\text { Gestation } \\
\text { (days) }\end{array}$ & Type of Labor & $\begin{array}{c}\text { Time required to suppress uterine } \\
\text { activity (min.) }\end{array}$ & $\begin{array}{c}\text { Recovery to pre-infusion } \\
\text { level (min.) }\end{array}$ \\
\hline B33 & 171 & Spontaneous & Immediate & 1 & 23 \\
B35 & 170 & Spontaneous & Immediate & 7 & 25 \\
B36 & 170 & Spontaneous & Immediate & 8 & 30 \\
B96 & 171 & Induced & Immediate & 1 & 24 \\
B108 & 170 & Induced & Immediate & 5 & 10 \\
B965 $*$ & 150 & Spontaneous & 2 & 5 & 16 \\
B965 b* & 150 & Spontaneous & Immediate & 6 & 18 \\
\hline
\end{tabular}

* Tested twice.

Tab. 3. Effect of prolonged administration of diazoxide in low dosage on uterine activity (Group III).

\begin{tabular}{|c|c|c|c|c|c|c|c|}
\hline \multirow[t]{2}{*}{ Animal } & \multirow{2}{*}{$\begin{array}{l}\text { Gestation } \\
\text { (Days) }\end{array}$} & \multirow[t]{2}{*}{ Type of Labor } & \multirow{2}{*}{$\begin{array}{l}\text { Total dose } \\
\text { (mg/kg) }\end{array}$} & \multirow{2}{*}{$\begin{array}{c}\text { Diazoxide } \\
\text { Infusion rate } \\
\text { (mg/kg/min.) }\end{array}$} & \multirow{2}{*}{$\begin{array}{c}\text { Duration of } \\
\text { infusion } \\
\text { (hours) }\end{array}$} & \multicolumn{2}{|c|}{$\begin{array}{l}\text { Time required to suppress } \\
\text { uterine activity (min.) }\end{array}$} \\
\hline & & & & & & $50 \%$ suppression & complete \\
\hline B452 & 158 & Spontaneous & 12.5 & 0.043 & 5 & 60 & 235 \\
\hline $\mathrm{B} 90$ & 153 & Spontaneous & 12.9 & 0.057 & 4 & 15 & 120 \\
\hline $\mathrm{B} 411$ & 165 & Spontaneous & 18.8 & 0.046 & 7 & 42 & NR* \\
\hline B108 & 154 & Spontaneous & 19.6 & 0.056 & 6 & 13 & 85 \\
\hline B124 & 151 & Spontaneous & 21.0 & 0.055 & 6 & 16 & 313 \\
\hline
\end{tabular}

\footnotetext{
* Never reached
} 
$6 \mathrm{mg} / \mathrm{kg}$, there was an almost immediate reduction of uterine activity, and complete suppression within 8 minutes (tab. 2). The inhibition was, however, short-lived. Activity began to appear in 10 minutes and within 30 minutes or less it returned to the pre-infusion level. In the third group of animals where uterine activity was mild, and diazoxide was infused very slowly in low concentration, the response was more gradual (tab. 3). Uterine activity was suppressed by $50 \%$ in approximately 30 minutes and reduced completely or to a very low level by one hour.

In the 10 control animals, uterine activity either remained at the same level or increased as labor progressed, the intensity being in the range of 200 Montevideo units.

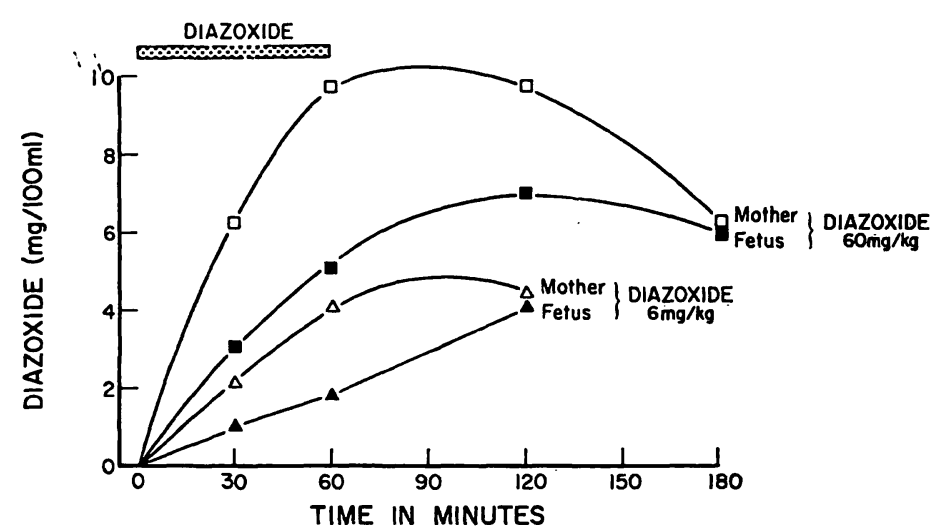

Fig. 2. Mean concentration of diazoxide in maternal and fetal arterial blood following intravenous infusion of diazoxide to the mother. The two upper curves are from 3 experiments where the mother was given $60 \mathrm{mg} / \mathrm{kg}$, and the lower curves from 3 experiments with $6 \mathrm{mg} / \mathrm{kg}$.

\subsection{Placental transfer of diazoxide (fig. 2)}

Diazoxide readily crossed the placenta and after 60 minutes of infusion blood levels in the fetus had reached $50 \%$ of that in the mother. The level in maternal blood remained high for 60 minutes after completing the infusion, and during this time the level of drug in fetal blood continued to increase. Equilibrium between mother and fetus was reached 60 minutes after completing the infusion when $6 \mathrm{mg} / \mathrm{kg}$ were given and in 120 minutes when $60 \mathrm{mg} / \mathrm{kg}$ were given. In group III, when a dilute solution of diazoxide was given over several hours, the concentrations of drug in both maternal and fetal blood were similar and reached $10 \mathrm{mg}$ per $100 \mathrm{ml}$ by six hours (B 108, B 124, B 411).

\subsection{Maternal and fetal response to diazoxide infusion}

Blood Pressure and Heart Rate (tab. 5). Infusion of diazoxide resulted in a fall in arterial blood pressure and a rise in heart rate in both mother and fetus. Hypotension was most pronounced when a larger amount of the drug was administered. Fetal hypotension was, in most instances, proportionately greater than that seen in the mother except when the drug was given as a single bolus injection. The degree of maternal tachycardia was also dose related. Although fetal tachycardia occurred, the response was more variable, due probably to fetal asphyxia following

Tab. 4. Group IV (Control Group) Acid-base and circulatory changes in the mother and fetus from the pre-infusion values to the termination of saline infusion.

\begin{tabular}{|c|c|c|c|c|}
\hline & \multicolumn{2}{|c|}{ Mother } & \multicolumn{2}{|c|}{ Fetus } \\
\hline & Pre-infusion & End of infusion & Pre-infusion & End of infusion \\
\hline $\mathrm{pH}$ & $7.42 \pm 0.004 *$ & $7.41 \pm 0.014$ & $7.25 \pm 0.017$ & $7.19 \pm 0.039$ \\
\hline $\begin{array}{l}\mathrm{PCO}_{2} \\
\text { (mmHg) } \\
\text { Base }\end{array}$ & $33 \pm 1.5$ & $30 \pm 1.0$ & $45 \pm 2.2$ & $55 \pm 2.2$ \\
\hline $\begin{array}{l}\text { Deficit } \\
(\mathrm{mEq} / \mathrm{L})\end{array}$ & $3.4 \pm 0.53$ & $5.8 \pm 1.75$ & $6.5 \pm 1.07$ & $9.8 \pm 1.67$ \\
\hline $\begin{array}{l}\mathrm{PO}_{2} \\
(\mathrm{mmHg})\end{array}$ & $103 \pm 11.1$ & $115 \pm 10.8$ & $25 \pm 1.6$ & $23 \pm 0.7$ \\
\hline $\begin{array}{l}\text { MBP } \\
\text { (mmHg) } \\
\text { Heart }\end{array}$ & $99 \pm 5.4$ & $89 \pm 5.8$ & $47 \pm 2.5$ & $45 \pm 2.2$ \\
\hline $\begin{array}{l}\text { Rate } \\
\text { beats/min.) }\end{array}$ & $175 \pm 3.4^{\circ}$ & $156 \pm 6.1$ & $182 \pm 2.7$ & $195 \pm 3.2$ \\
\hline
\end{tabular}

* Values are mean \pm S. E. from 10 animals 


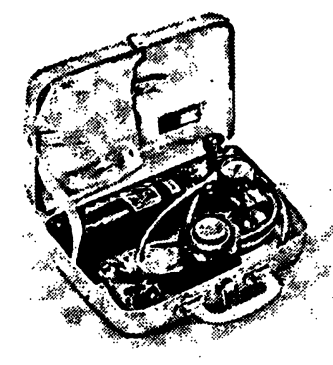

Alternating Pressure Respirator for New-Born Babies (according to Saling)

\section{THE AUER WB 66 BRINGS YOU UP TO DATE WITH PERINATALMEDICINE}

When reanimating asphyxia newborns a rapid insufflation of oxygen is indicated. This can be done with our alternating pressure respirator, which helps you in treating hypoxia and acidosis of newborns.

The respirator is called WB 66 and is built according to Prof. Saling. It is easy and safe in its applicationmuch more so than the WB 58 from which we developed it. The WB 66
Please send me your technical leaflet for the AUER WB 66

Name

Company

Street

City

Zip code

Auergesellschaft $\mathrm{GmbH}$, Medizintechnik

D1 Berlin 65, Friedrich-Krause-Ufer 24-34 ensures a full-fledged endotracheal respiration with oxygen or air under alternating pressure. The unit is so handy that you may take it along. This is only one of its advantages. What else is new with the AUER WB 66 our technical leaflet will tell you. Just mail us the coupon.

We protect people and their work. 


\section{Walter de Gruyter Berlin-New York}

\section{Boschann}

\section{Gynäkologische Zytodiagnostik für \\ Klinik und Praxis}

2nd entirely revised edition of

"Praktische Zytologie"

With 28 illus., of that 18 colored

and 110 line drawings. 1973.

Approx. 180 pp.

Bound DM 54, -; $\$ 19.00$

ISBN 3110039818

\section{Riedel}

\section{Urologische \\ Zytodiagnostik}

1973. VIII + 97 pp. with 61 illus.

and 8 colored plates. Bound $\$ 13.40$ ISBN 3110041189

\section{Martius}

\section{Geburtshilfe in Stichworten}

With the collaboration of Ulrich Magnus. 1972. 447 pp.

Boards DM 14,80; $\$ 5.20$

ISBN 3110042703

(Sammlung Göschen 7003)

\section{Mosler}

\section{Fetale Herzaktion}

\section{und Tokographie}

(Ultrasonographie)

Atlas für die Geburtshilfe.

With the collaboration of Edgar Kitz. 1972. XII + 105 pp. 78 illus. Boards DM 56,-; $\$ 19.70$

ISBN 3110042258

\section{Gitsch - Palmrich}

\section{Gynäkologisch- operative Anatomie}

Einfache und erweiterte Hysterektomie - Ein Atlas Appendix: Die RadioisotopenRadikaloperation. With an introduction by $H$. Husslein and I. Amreich. Illustration part by Hans Lang. 1972. XII + 162 pp. With 200 partly varicolored illus. Bound .DM 160,-; $\$ 56.25$ ISBN 3110034808

Pschyrembel

\section{Praktische} Geburtshilfe und geburtshilfliche Operationen

14th edition. With the collaboration of Priv. Doz. Dr. Jürg

Bretscher and Prof. Dr. Dietrich Hofmann. 1973. With 612 illus. XXVIII + 899 pp.

Bound DM 68, 一; $\$ 24.00$

ISBN 3110016833

\section{Pschyrembel - Dudenhausen}

\section{Grundriß der Perinatalmedizin}

1972. IV + 336 pp. With 140 illus. and charts.

Plastic cover DM 38,-; $\$ 13.40$ ISBN 3110036940

\section{Pschyrembel}

\section{Praktische}

\section{Gynäkologie}

Für Studierende und Ärzte

4 th revised and enlarged edition. 1968. XXIV + 642 pp. 503 partly varicolored illus.

Bound DM 54,-; $\$ 19.00$.

ISBN 3110008068 
Tab. 5. liffect of diazoxide on blood pressure and heart sate of mother and fetus.

\begin{tabular}{|c|c|c|c|c|c|c|c|c|c|c|c|c|c|}
\hline & & & & Mothe & & & & & & Fetus & & & \\
\hline Ani & & $\begin{array}{l}\text { Initial } \\
\text { MBPי } \\
\left(\mathrm{mmH}_{\mathbf{g}}\right)\end{array}$ & $\begin{array}{l}\text { lues } \\
\text { HR } \\
\text { ars } / \mathrm{min})\end{array}$ & $\begin{array}{c}\text { Chan } \\
\text { cnd } \\
\text { infusi } \\
\text { MBP }\end{array}$ & $\begin{array}{l}\text { at } \\
\text { of } \\
\text { HR }\end{array}$ & $\begin{array}{l}\text { Time } \\
\text { to pre } \\
\text { value } \\
\text { MBP }\end{array}$ & $\begin{array}{l}\text { recover } \\
\text { afusioa } \\
\text { min)*"* } \\
\text { HR }\end{array}$ & 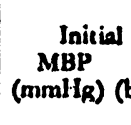 & $\begin{array}{l}\text { lues } \\
\text { HR } \\
(1 / / \mathrm{min})\end{array}$ & $\begin{array}{l}\text { Chang } \\
\text { cnd } \\
\text { infusior } \\
M B P\end{array}$ & $\%$ & $\begin{array}{l}\text { Time to } \\
\text { to pre-in } \\
\text { value (m } \\
\text { MIBP }\end{array}$ & $\begin{array}{l}\text { cover } \\
\text { usion } \\
\text { P.) } \\
\text { HR }\end{array}$ \\
\hline Group I & R25 & 100 & 180 & -2 & +22 & 60 & 60 & 45 & 200 & -13 & +10 & NR & NR \\
\hline$N: 10$ & R20 & 113 & 240 & -3 & +19 & 60 & 60 & 44 & 180 & -18 & +16 & NR & 30 \\
\hline & 1338 & 97 & 140 & -18 & +16 & 90 & $N_{R}{ }^{\cdots \cdot}$ & 46 & 140 & -28 & +2 & NR & 10 \\
\hline & 18 & 88 & 180 & -21 & +33 & 60 & NR & 47 & 195 & -43 & +13 & NR & NR \\
\hline & R14 & 95 & 210 & -23 & +30 & 30 & NR & 50 & 170 & -10 & +24 & 60 & 30 \\
\hline & $\mathrm{J} 16$ & 87 & 165 & -55 & +57 & 120 & NR & 53 & 150 & -45 & +13 & NR & NR \\
\hline & $\mathrm{J} 10$ & 85 & 190 & -39 & +26 & NR & NR & 47 & 170 & -47 & +2 & NR & 60 \\
\hline & R24 & 86 & 200 & -51 & +20 & NR & NR & 43 & 140 & -63 & +18 & NR & 30 \\
\hline & $\mathrm{J} 17$ & 90 & 210 & -26 & +14 & NR & NR & 45 & 195 & -44 & +13 & NR & NR \\
\hline & J19 & 95 & 225 & -56 & +18 & NR & NR & 35 & 200 & -46 & +5 & NR & NR \\
\hline & Mcan & 93 & 194 & -29 & +26 & - & - & 46 & 174 & -36 & +12 & - & - \\
\hline & 土S.E. & \pm 2.7 & \pm 9.3 & \pm 6.3 & \pm 3.9 & 10 & 10 & \pm 1.6 & \pm 7.5 & \pm 5 & \pm 2.2 & - & - \\
\hline Group II & Mcan & 92 & 141 & -15 & +35 & 10 & 10 & 47 & 167 & -16 & +7 & 60 & 60 \\
\hline$N: 6$ & 土S.E. & \pm 2.1 & \pm 6.5 & \pm 5.1 & \pm 5.2 & - & - & \pm 1.7 & \pm 6.2 & \pm 4.1 & \pm 2.7 & - & - \\
\hline Group 111 & Mcan & 92 & 130 & -5 & +36 & - & - & 45 & 180 & -15 & +15 & - & - \\
\hline$N: 5$ & 土S.E. & \pm 8.2 & \pm 5.5 & \pm 4.1 & \pm 4.8 & - & - & \pm 3.1 & \pm 8.4 & \pm 6.1 & \pm 1.3 & - & - \\
\hline Group IV & Mcan & 99 & 175 & -10 & -11 & - & - & 47 & 182 & -4 & +7 & - & - \\
\hline$N: 10$ & 土S.E. & \pm 5.4 & \pm 3.4 & \pm 5.0 & \pm 4.8 & - & - & \pm 2.5 & \pm 2.7 & \pm 2.2 & \pm 1.0 & - & - \\
\hline
\end{tabular}

* Mean arterial blood pressure

** Observation continued for over 3 hours

*** Never recovered to the initial value.

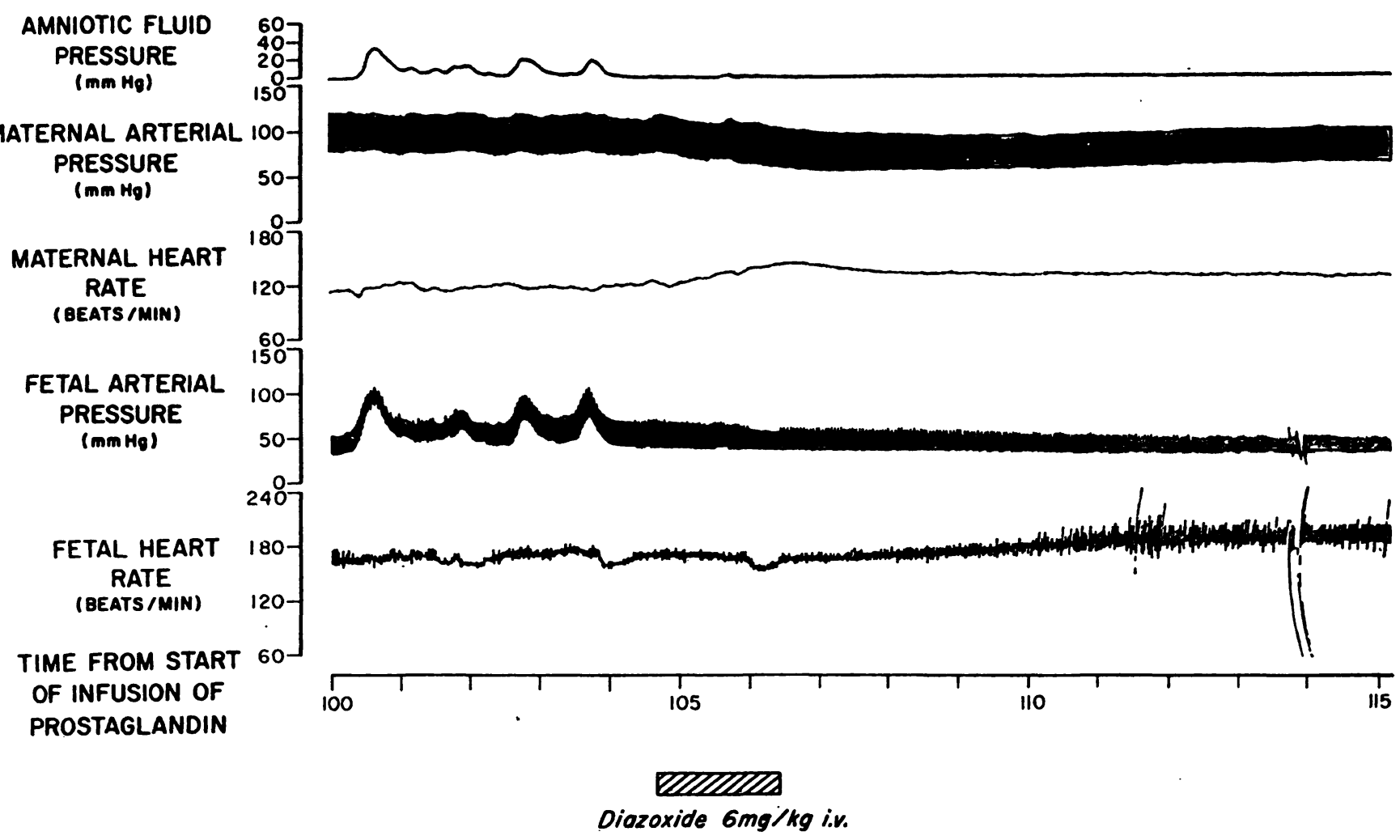

Fig. 3. Effect of a single bolus injection of diazoxide on uterine activity induced with prostaglandin $F_{2} \alpha$. Note the immediate cessation of uterine activity and the onset of maternal hypotension and tachycardia followed by the development of fetal hypotension and tachycardia with a lag time of 2 to 3 minutes. 
maternal and fetal hypotension. Changes in maternal heart rate and blood pressure began within a minute of diazoxide administration and the corresponding changes in fetal cardiovascular status were seen $2-3$ minutes later, reflecting the rapid placental transfer. This was clearly demonstrated in the experiments where a bolus of diazoxide was given (fig. 3); it was also seen when the drug was given as a constant infusion (fig. 1). Mild hypotension and tachycardia were also seen in those animals receiving a prolonged infusion at a low concentration (group III), but the changes were not significant.

Recovery of maternal blood pressure and heart rate was most rapid in those animals receiving the drug as a single bolus injection, occurring in approximately 10 minutes (groupII). In the animals receiving a total dose of $6-12 \mathrm{mg} / \mathrm{kg}$ as a continuous infusion (group I) recovery rate was much slower (30 to 120 minutes). When a larger dose was given, hypotension and tachycardia persisted for over three hours of observation, after the infusion had been completed. Recovery of fetal blood pressure occurred slowly even in the single injection group. In only one fetus in group I, had it returned to the control level after 1 hour of observation. In those experiments where the mother received a larger dose of diazoxide, severe fetal hypotension persisted throughout the period of observation.

The time during which fetal tachycardia persisted after completing the infusion was variable. In the bolus injection, group II, it remained for 60 minutes and in half of the animals in group I, it was still present after 3 hours. Late deceleration of the fetal heart rate, which was seen in 3 animals in each of groups I and II, disappeared when uterine activity was inhibited by infusion of diazoxide (fig. 1).

\subsection{Blood $\mathrm{pH}$ and gas tensions}

Maternal acid-base state remained stable during the operation and recovery period. Mean pre-infusion values were $\mathrm{pH} 7.42 \pm 0.001$ (S. E.), $\mathrm{P}_{\mathrm{CO}_{2}} 32 \pm 11.5 \mathrm{mmHg}$, base deficit $3.2 \pm 0.62$ $\mathrm{mEq} / \mathrm{L}$, and $\mathrm{P}_{\mathrm{O}_{2}} 104 \pm 10.9 \mathrm{mmHg}$. A slight metabolic acidosis developed as labor progressed but this was compensated for by a fall in $\mathrm{P}_{\mathrm{CO}_{2} \text {. }}$.

Changes in fetal acid-base state are presented in tab. 6. In those experiments where labor was

Tab. 6. Arterial blood $\mathrm{pH}, \mathrm{PCO}_{2}$, base deficit and $\mathrm{PO}_{2}$ of the fetus before and at the termination of administration of diazoxide.

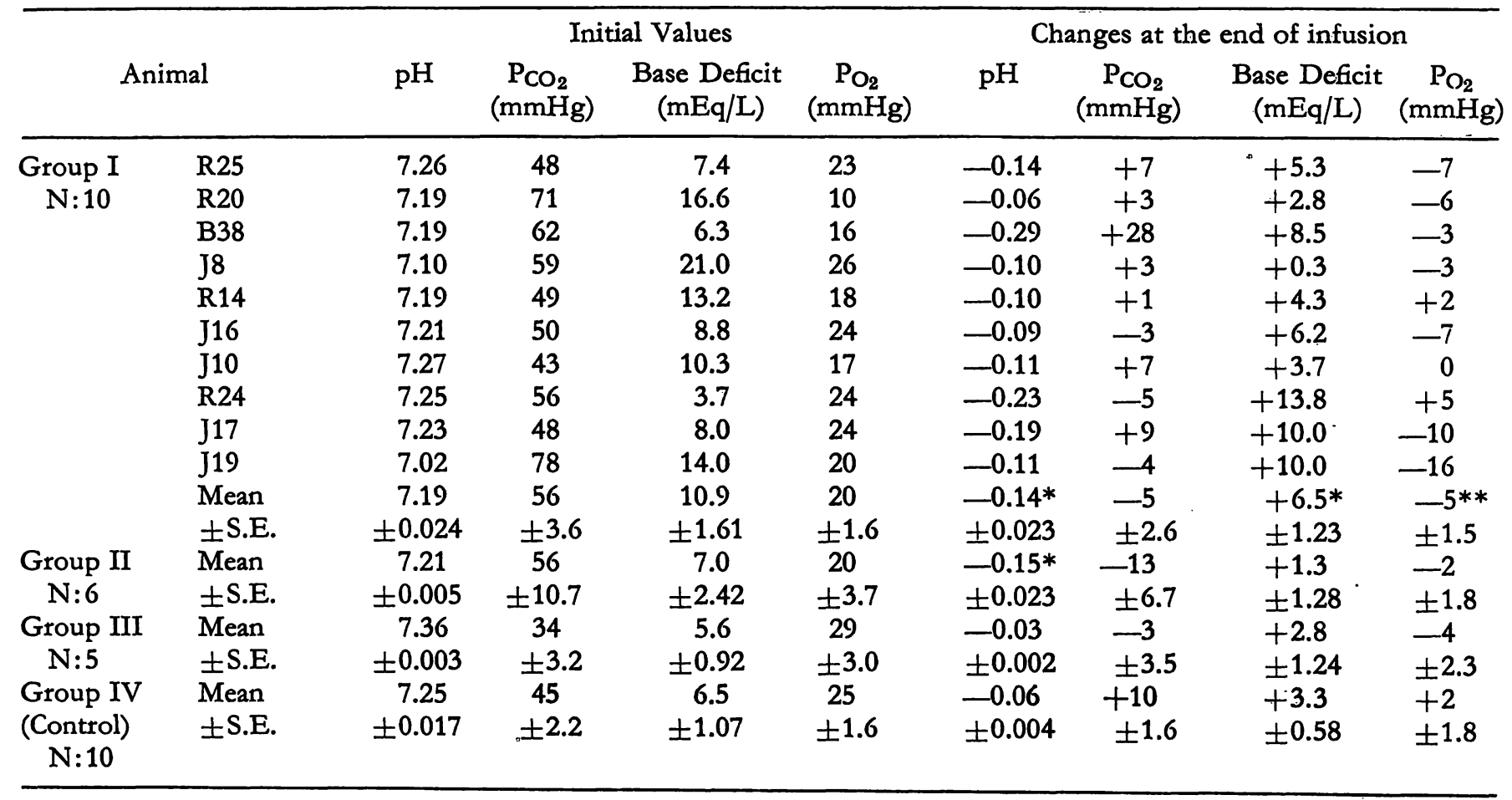

* Significant, $\mathrm{p}<0.01$

** Significant, $\mathrm{p}<0.05$ 
well-cstablished, varying degrees of fetal acidosis were present at the end of the control period (sce initial values groups I, II, and IV). In group 111, where only mild contractions occurred, acid-base state remained normal. Fetal acidosis increased significantly during and following infusion of diazoxide in group $\mathrm{I}$ and II. A slight fall in $\mathrm{pH}$ was also observed in group III (low dosage) and group IV (control) over the same time interval, but these changes were not significant. Fetal $P_{\mathrm{O}_{2}}$ values were normal in all but 2 animals at the end of the control period. Infusion of diazoxide was accompanied by a fall in $\mathbf{P}_{\mathbf{O} 2}$ which was significant in group I. 'Thus, despitc inhibition of utcrinc activity, $\mathrm{P}_{\mathrm{O}_{2}}$ fell in general. A small rise in fetal $\mathrm{P}_{\mathrm{O}_{2}}$ was actually observed in $3 \mathrm{cx}$ periments, but was not of a sufficient order to prevent progressive increase in fetal acidosis.

\subsection{Blood glucose levels}

Glucose concentrations in arterial blood were measured in 14 experiments, all animals in group I, and 4 in group III. In the first group, mean pre-

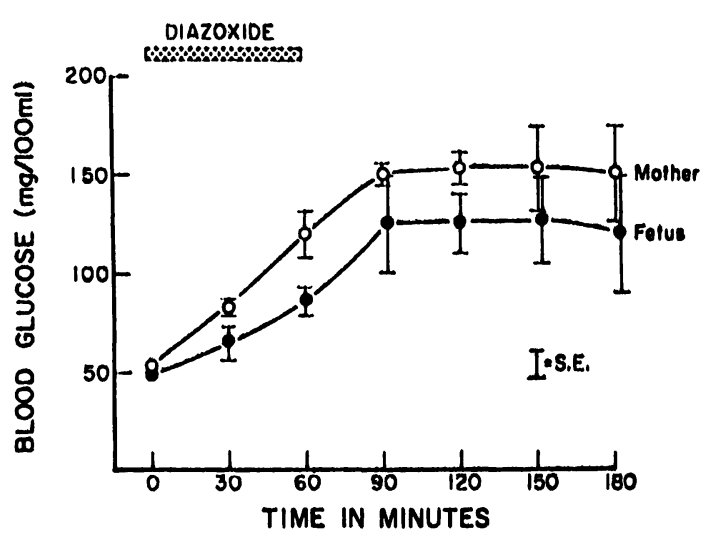

Fig. 4. Mean blood sugar levels of mother and fetus during and following infusion of diazoxide in 10 experiments. S. E. $=$ Standard Error.

infusion levels in mother and fetus were $53.7 \pm$ 2.52 and $49.2 \pm 2.78 \mathrm{mg} / 100 \mathrm{ml}$, respectively. There was a rapid increase in blood glucose of both mother and fetus following administration of diazoxide which reached a platenu

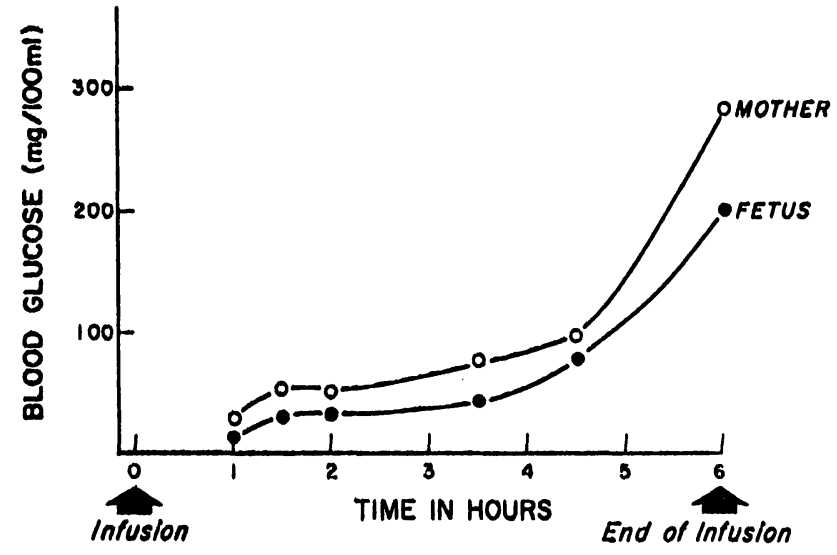

Fig. 5. Mcan blood sugar levels in mother and fetus during prolonged infusion of diazoxide at low concentrations (4 animals in group III).

30 minutes after completing the infusion. Hyperglycemia persisted for over 150 minutes. The standard errors werc large because of different doses of diazoxide. Glucose levels in fetal blood were consistently lower than those in maternal blood (fig. 4). When diazoxide was infused slowly in a low concentration (fig. 5), no hyperglycemic response was observed in either mother or fetus for over 4.5 hours. Thereafter, glucose levels increased in a parallel fashion.

\section{Discussion}

The purpose of these experiments was to determine the effect of diazoxide on the fetus. The effectiveness of the drug in suppressing uterine activity was confirmed, regardless of whether labor was spontancous or induced; uterine contractions could be suppressed in induced labor, even though the myometrial stimulating agent, oxytocin or prostoglandin $\mathrm{F}_{2} \alpha$, was continuously being infused. However, certain adverse effects were noted. In order to suppress well-established labor, the dose of dinzoxide required, also caused maternal hypotension. The drug readily crossed the placenta and caused fetal hypotension which persisted in some cases. for several hours, probably because the drug has. a long half-life [14].

The bolus injection was most effective in producing an immediate cessation of utcrine activity but the action was of relatively short duration and was associated with significant 
Tab. 7. Change in $\mathrm{pH}$ during a 3 hour recovery period in 42 fetuses following fetal surgery.

\begin{tabular}{lrccr}
\hline $\begin{array}{l}\text { Postoperative Period } \\
\text { (min.) }\end{array}$ & $\mathrm{N}$ & $\begin{array}{c}90-120 \\
\text { (Recovery) }\end{array}$ & $121-180$ & $\Delta \mathrm{pH}$ \\
\hline Not in labor & 14 & $7.31 \pm 0.020$ & $7.32 \pm 0.023$ & $-0.018 \pm 0.0192$ \\
In labor & 7 & $7.33 \pm 0.017$ & $7.29 \pm 0.003$ & $-0.038 \pm 0.0012$ \\
(mild acidosis) & 21 & $7.22 \pm 0.036$ & $7.17 \pm 0.054$ & $-0.061 \pm 0.0123$ \\
$\begin{array}{l}\text { In labor } \\
\text { (moderate acidosis) }\end{array}$ & & & & \\
\hline
\end{tabular}

hypotension. Despite this adverse effect on the fetus, the drug might prove to be very useful for the emergency management of tetanic uterine contractions. The drug was effective and without adverse effects on mother and fetus when given in low dosage over a prolonged period of time for the control of mild uterine contractions.

Diazoxide administration was followed by the development of acidosis and hypotension in fetuses in groups I and II. The degree of acidosis which developed was significantly greater than that seen in the control group in this series. It might be argued that the fetal deterioration was the result of the operative procedure and long observation period, rather than the action of the drug itself on maternal and fetal hemodynamics. The stable condition of animals in group III, where only small doses of diazoxide were administered over several hours, without the development of fetal hypotension or acidosis does not support such an interpretation. Serial observations of acid-base state over a similar time period have been made in 42 earlier experiments (tab. 7). Fetal acidosis did not develop if the uterus remained quiescent. If labor began spontaneously or was artificially induced, some degree of acidosis developed in all fetuses, similar to that seen in normal labor in humans. This was relatively mild in those fetuses which were not acidotic when uterine contractions began. Fetuses which were more acidotic at the onset of labor, probably as a result of some compromise in maternal-fetal perfusion of the intervillous space and fetal villi, became more severely acidotic as labor progressed. The degree of acidosis seen in the present experiments in fetuses of group I and II, whose mothers received relatively large doses of diazoxide, was of a comparable degree to that which developed during labor in some animals in our previous experiments. However, with diazoxide infusion, the acidosis developed more rapidly, 60 minutes as compared to 120 to 180 minutes in earlier experiments. Furthermore, the acidosis persisted despite the abolition of uterine contractions. It would appear, therefore, that the diazoxide administration to the mother was an important factor in the development of fetal acidosis probably because of maternal and fetal hypotension. Prolonged fetal hypotension due to the long half-life of the drug is also likely to have contributed to the persistence of the acidosis, although uterine contractions have been abolished. More severe degrees of fetal asphyxia also cause hypotension. However, hypotension seen in these experiments was of a more rapid onset and of a much greater degree than observed in earlier experiments with a similar order of fetal acidosis [7].

Maternal blood glucose levels during the control period (fig. 4) were within normal range [13] for rhesus monkeys; the fetal values were slightly elevated, as a result of the mild acidosis and hypoxia [4]. The hyperglycemic response in both mother and fetus was prompt and sustained. No adverse effect of such hyperglycemia has been described for the adult. It is not known whether or not prolonged hyperglycemia in the fetus might have some untoward effect.

Our laboratory has in recent years conducted similar experiments to examine the inhibitory effect of both ethanol [6] and orciprenaline

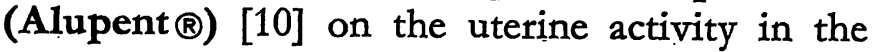
subhuman primate. Diazoxide has been proven to be the most effective of these three drugs in suppressing both spontaneous or artificially induced labor. In particular it was the only drug which effectively stopped well-estab- 
lished spontaneous labor although all three were effective if only mild contractions of early labor were present. It was also the only drug which suppressed artificially induced contractions when given concommitantly with the myometrial stimulating agent.

All three drugs had some adverse effects. The dose of ethanol necessary to inhibit contractions produced maternal respiratory depression, fetal hypotension and acidosis. Örciprenaline resulted in mild hypotension and tachycardia in the mother, but quite marked fetal hypotension and acidosis. While diazoxide was the most effective drug, it also caused the most severe hypotension. Because of this, it cannot be considered the ideal agent for suppressing uterine activity. From our experiments, it would seem that diazoxide is useful for emergency management of tetanic contractions and in low dosage for suppression of premature labor. If employed, particular attention should be paid to the monitoring of maternal blood pressure and fetal heart rate. Should the fetus be born even several hours after the drug has been administered, the newborn may be hypotensive.

\section{Summary}

The inhibiting action of diazoxide*, a benzothiadiazine derivative, a smooth muscle relaxant on spontaneous and induced labor, placental transfer of the drug and its effect on the cardiovascular and biochemical state of both mother and fetus has been studied in 31 subhuman primates. Catheters were placed in the fetal carotid artery or femoral artery and amniotic fluid at hysterotomy, and in the maternal femoral artery and vein. In addition, thermistor probes were placed in the fetal esophagus and maternal rectum. Maternal and fetal arterial pressure, heart rate, and amniotic fluid pressure were monitored and recorded continuously. Following the operative procedure, uterine contractions commenced spontaneously in 20 animals. In the remaining 11 , uterine contractions were induced with oxytocin or prostaglandin $\mathrm{F}_{2} \alpha$. Diazoxide was infused intravenously into 21 animals while isotonic saline was infused into the remaining 10, which formed a control group. The drug was administered in three ways: (a) in a graded dose to determine dose response, (b) as a bolus in an attempt to suppress uterine activity acutely, (c) in a low dosage as a slow, prolonged infusion with only mild uterine activity.

There was a reduction in the intensity of uterine activity within a few minutes of commencing the diazoxide infusion and within 30 minutes there was a $50 \%$ suppression of activity, irrespective of whether labor was spontaneous or induced (fig. 1). Following the termination of diazoxide, sustained inhibition continued for 30 minutes or longer, and in those animals receiving the largest dose, the inhibiting action lasted for over 2 hours (tabs. 1 to 3 ). Diazoxide readily crossed the placenta and after 60 minutes of infusing the drug, blood levels in the fetus had reached $50 \%$ of maternal level (fig. 2). Equilibrium between mother and fetus was reached 60 minutes after completing the infusion when $6 \mathrm{mg} / \mathrm{kg}$ were given and in

\footnotetext{
* Hyperstat ${ }^{\circledR}$ (Schering Corporation, USA).
}

120 minutes when $60 \mathrm{mg} / \mathrm{kg}$ were given. Infusion of diazoxide resulted in a fall in arterial blood pressure and a rise in heart rate in both mother and fetus (tab. 4). Hypotension was most pronounced when a larger amount of the drug was administered. Changes in maternal heart rate and blood pressure began within a minute of diazoxide administration and the corresponding changes in fetal cardiovascular status were seen 3-7 minutes later, reflecting the rapid placental transfer (fig. 3). Recovery of maternal blood pressure and heart rate was most rapid in those animals receiving the drug as a single bolus injection. When a larger dose was given, hypotension and tachycardia persisted for over three hours of observation, after the infusion had been completed (tabs. 4 and 5).

Late deceleration of the fetal heart rate disappeared when uterine activity was inhibited by infusion of diazoxide. Maternal acid-base state remained stable throughout the experiment (tab. 6); a slight metabolic acidosis developed as labor progressed but this was compensated for by a fall in $\mathrm{PCO}_{2}$. Varying degrees of fetal acidosis were present at the end of the control period in those experiments where labor was well-established. The degree of fetal acidosis increased significantly during and following infusion of diazoxide (tab. 7).

There was a rapid increase in blood glucose of both mother and fetus following administration of diazoxide which reached a plateau 30 minutes after completing the infusion (figs. 4 and 5). Hyperglycemia persisted for over 150 minutes.

The effectiveness of diazoxide in suppressing uterine activity was confirmed, regardless of whether labor was spontaneous or induced. Certain adverse effects were noted. The dose required to suppress well-established labor also caused maternal hypotension. The drug was effective and without adverse effects on mother and fetus when en given in low dosage over a prolonged period of time for the control of mild uterine contractions.

Keywords: Acid-base state, diazoxide, fetus, placental transfer, primate, oxytocin, prostaglandin, uterine activity. 


\section{Zusammenfassung}

Die Hemmwirkung von Diazoxide auf die Wehentätigkeit beim subhumanen Primaten: Plazentarer Transfer und Wirkung auf den Fetus

Die hemmende Wirkung von Diazoxide*, einem Benzothiadiazidabkömmling mit relaxierender Wirkung auf die glatte Muskulatur, auf spontane und induzierte Wehentätigkeit sowie der plazentare U̇bertritt des Mittels und seine Einwirkung auf den mütterlichen und fetalen kardiovaskulären und biochemischen Status wurde an 31 subhumanen Primaten untersucht. Katheter wurden in die A. carotis oder femoralis des Feten und in den liquor amnii durch eine Hysterotomie eingeführt sowie in die mütterliche A. und V. femoralis. Außerdem wurden Thermistorsonden im Oesophagus des Feten und das Rektum des Muttertieres plaziert. Arterielle Drucke von Fet und Mutter, Pulsfrequenz und Liquordruck wurden fortlaufend überwacht und registriert. Spontane Wehentätigkeit begann bei 20 Tieren nach der Operation. Bei den übrigen 11 Tieren wurde die Wehentätigkeit mit Oxytocin ioder Prostglandin $\mathrm{F}_{2} \alpha$ angeregt. Diazoxide wurde 21 Tieren intravenös infundiert; den restlichen 10 wurde als Kontrollgruppe physiologische Kochsalzlösung gegeben. Das Medikament wurde in dreierlei Weise verabreicht: a) in abgestufter Dosierung, um die Dosisreaktion festzustellen; b) in einem Bolus, in einem Versuch, die Uterusaktivität akut zu unterdrücken; c) in niedriger Dosierung als langsame Infusion bei nur leichter Uterusaktivität.

Es erfolgte eine Herabsetzung der Intensität der Uterusaktivität innerhalb weniger Minuten nach Beginn der Diazoxide-Infusion und nach 30 Minuten fand sich eine 50-prozentige Unterdrückung der Aktivität induzierter und spontaner Wehentätigkeit (Abb. 1). Nach Beendigung der Diazoxide-Infusion blieb die Hemmung für 30 Minuten oder länger bestehen; bei den Tieren mit der höchsten Dosis hielt die Hemmung über 2 Stunden an (Tab. 1-3). Diazoxide weist einen schnellen plazentaren Ửbertritt auf, nach 60-minütiger Infusion betrugen die Konzentrationen in den Feten $50 \%$ der mütterlichen Werte (Abb. 2). Ein Gleichgewicht zwischen Mutter und Fet war 60 Minu-

* Hyperstat $®$ (Schering Corporation, USA).

Schlüsselwörter: Säure-Basen-Status, Diazoxide, Fetus, Uterusaktivität, Wehenhemmung.

\section{Résumé}

L'action inhibitrice de la diazoxide* sur la contraction uterine chez le singe primate: passage placentaire et effet sur le foetus

L'effet de la Diazoxide (dérivé de la Benzothiazine à action myorelaxante pour la fibre lisse) a été étudié chez 31 singes primates.

* Hyperstat $®$ (Schering Corporation, USA). ten nach Beendigung der Infusion von $6 \mathrm{mg} / \mathrm{kg}$ und 120 Minuten nach einer Gabe von $60 \mathrm{mg} / \mathrm{kg}$ erreicht. Die Diazoxide-Infusion führte zum Abfall des arteriellen Blutdruckes und zum Anstieg der Herzfrequenz sowohl des Muttertieres als auch des Feten (Tab. 4). Die Hypotension war am stärksten ausgeprägt nach höherer Dosierung. Veränderungen des mütterlichen Pulses und Blutdruckes begannen innerhalb einer Minute nach Diazoxide; die entsprechenden fetalen Veränderungen wurden 2-3 Minuten später beobachtet, dem raschen Plazentarübertritt entsprechend (Abb. 3). Die Normalisierung des mütterlichen Pulses und Blutdruckes erfolgte am schnellsten bei denjenigen Tieren, welche das Mittel in einem einzigen Bolus erhalten hatten. Nach höherer Dosierung bestanden Hypotension und Tachykardie für über 3 Stunden nach Beendigung der Infusion (Tab. 4 und 5).

Späte Dezelerationen der fetalen Herzfrequenz verschwanden nach Hemmung der Uterusaktivität durch Diazoxide. Der mütterliche Säure-Bàsen-Status blieb stabil während des Experimentes (Tab. 6), eine leichte metabolische Azidose, welche durch einen Abfall des $\mathrm{PCO}_{2}$ kompensiert wurde, erschien nach anhaltender Wehentätigkeit. Unterschiedliche Ausmaße von fetaler Azidose wurden am Ende der Kontrollperiode derjenigen Experimente beobachtet, bei welchen aktive Wehentätigkeit bestand. Das Ausmaß der fetalen Azidose war signifikant höher während und nach der Diazoxide-Infusion (Tab. 7).

Ein rascher Anstieg des mütterlichen und fetalen Blutzuckers nach Diazoxide wurde beobachtet, welcher ein Plateau 30 Minuten nach Beendigung der Infusion erreichte (Abb. 4 und 5). Die Hyperglykämie bestand für über 150 Minuten.

Die Wirksamkeit des Diazoxide, Uterusaktivität zu hemmen, wurde bestätigt, gleich ob bei spontaner oder induzierter Wehentätigkeit. Gewisse ungünstige Nebenwirkungen wurden beobachtet. Die notwendige Dosis für die Unterdrückung aktiver Wehen verursacht mütterliche Hypotension. Das Medikament war wirksam und ohne ungünstige Nebenwirkungen auf Mutter und Fet wenn es niedrig dosiert während eines längeren Zeitraumes zur Hemmung leichter Wehentätigkeit gegeben wurde.

La drogue agit rapidement sur la contraction utérine qui diminue de $\mathbf{5 0} \%$ en $\mathbf{3 0}$ minutes, que le travail soit spontané ou induit (fig. 1). L'effet dure 30 minutes après la fin de la perfusion et jusqu'à $2 \mathrm{~h}$ en cas de forte dose (Tab. 1 à 3).

La Diazoxide traverse facilement le placenta. Au bout d'une heure de perfusion, le taux sanguin foetal a atteint $50 \%$ du taux maternel (fig. 2). L'équilibre entre les taux 
sanguins maternel ct foetal est atteint en 60 minutes si la perfusion est de $6 \mathrm{mg} / \mathrm{kg}$, en 120 ou si la dose est de $120 \mathrm{mg} / \mathrm{kg}$.

La Diazoxide entraine une hypotension artérielle et une tachycardie chez la mère et chez l'enfant (tab. 4). Il disparaît vite en cas de dose unique injectée rapidement; plus lentement (jusqu'à trois heures) en cas de dose importante (tab. 4 et 5). Des ralentissements tardifs du rythme cardiaque foetal disparaissent lorsque la contraction est bloquée par la Diazoxide. L'équilibre acido basique reste inchangé chez la mère (tab. 6) tandis que, se développe une légère acidose foetale, compensée par une baisse de la $\mathrm{P}_{\mathrm{CO}_{2}}$, mais qui croît tout au long et après la perfusion (tab. 7). Il se produit une hyperglycémie maternelle et foetale, maxima, puis au bout de 30 minutes (fig. 4 et 5), puis en plateau pendant 150 minutes.

Il se confirme donc que la Diazoxide est capable de bloquer les contractions utérines, spontanées ou provoquées; la dose efficace entraine des effets secondaires, notamment une hypotension maternelle. Administrée à faible dose et assez longtemps, elle est en revanche efficace, sans effet nocif maternel ou foetal, pour stopper des contractions utérines d'intensité moyenne.

Mots-dés: Acide base, Diazoxide, Foetus, Ocytocine, Passage placentaire, Primate, Prostaglandine, Contraction utérine.

\section{Acknowledgement}

This investigation was supported by the United States Public Health Service, Grant GM09069, and was conducted in collaboration with the Laboratory for Experimental Medicine and Surgery in Primates (LEMSIP).

\section{Bibliography}

[1] Caldeyro-Barcia, R., Y. Sica-Blanco, J. J. Poseiro, V. Gonzalez Panizza, C. Mendez-Bauer, C. Fielitz, H. Alvarez, S. V. Pose, C. H. Hendricks: A quantitative study of the action of synthetic oxytocin on the pregnant human uterus. J. Pharmacol. Exper. Therap. 121 (1957) 18

[2] Calesnick, B., B. Kachen, J. Black: Importance of dissolution rates in producing effective diazoxide blood levels in man. J. Pharmac. Sci. 54 (1965) 1277

[3] Daniel, E. E., C. W. Nash: The effects of diuretic and non-diuretic benzothiadiazine and of structually related diuretic drugs on active ion transport and contractility in smooth muscles. Arch. Int. Pharmacodyn. 158 (1965) 139

[4] Dawes, G. S., H. N. Jacobson, J. C. Motr, H. J. SHELLEY, A. STAFFORD: The treatment of asphyxiated, mature foetal lambs and rhesus monkeys with intravenous glucose and sodium carbonate. J. Physiol. 169 (1963) 167

[5] Finnerty, F. A., JR., N. Kakaviatos, J. Tuckman, J. Maginl: Clinical evaluation of diazoxide: A new treatment for acute hypertension. Circulation 28 (1963) 203

[6] Horiguchi, T., K. Suzuki, A. C. Comas-Urrutia, E. Mueller-Heubach, A. M. Boyer-Mrlic, H. O. Morishima, L. S. James, K. Adamsons: Effect of ethanol upon uterine activity and fetal acid-base state of the thesus monkey. Amer. J. Obstet. Gynec. 109 (1971) 910
[7] James, L. S., H. O. Morishima, S. S. Daniel, E. T. Bowe, H. Cohen, W. H. Niemann: Mechanism of late deceleration of the fetal heart rate. Amer. J. Obstet. Gynec. 113 (1972) 578

[8] Landesman, R., J. A. De Souza F., E. M. Coutinho, K. H. Wirson, M. B. DE SouzA, F.: The inhibitory effect of diazoxide in normal term labor. Amer. J. Obstet. Gynec. 103 (1969) 430

[9] Landesman, R., K. H. Wilson: The relaxant effect of diazoxide on isolated gravid and nongravid human myometrium. Amer. J. Obstet. Gynec. 101 (1968) 120

[10] Morishima, H. O., M. Finster, W. H. Niemann, L. S. James: Unpublished data

[11] Morishima, H. O., S. S. Daniel, T. Sugiura, L. S. JAMES: Unpublished data

[12] Morishima, H. O., A. I. Hyman, K. Adamsons, L. S. JAMES: Anesthetic management for fetal operation in the subhuman primate. Amer. J. Obstet. Gynec. 110 (1971) 926

[13] Shelly, H. J., G. A. Neligan: Neonatal hypoglycaemia. Brit. Med. Bull. 22 (1966) 34

[14] Symchowicz, S., L. Winston, J. Black, M. Smith, B. Calesnick, I. I. A. TabachinrCk: Diazoxide blood levels in man. J. Pharmac. Sci. 56 (1967) 915

[15] Whol, A. J., L. M. Hausler, F. E. Roth: Studies on the mechanism of antihypertensive action of diazoxide: In vitro vascular pharmacodynamics. J. Pharmacol. Exper. Therap. 158 (1967) 531

\author{
Dr. Hisayo O. Morishima \\ Division of Perinatal Medicine of the \\ Dept. of Anesthesiology, Obstetrics and \\ Gynecology and Pediatrics \\ College of Physicians and Surgeons \\ Columbia University \\ 630 West 168th Street \\ New York, N. Y. 10032/USA
}

